\title{
SOSIALISASI GERAKAN KELUARGA SADAR OBAT (GKSO) DI DESA TABORE KECAMATAN MANTANGAI KABUPATEN KAPUAS KALIMANTAN TENGAH
}

\author{
Guntur Satrio P1, Dewi Sari Mulia ${ }^{1}$ dan Nurul Qamariah ${ }^{1}$ \\ ${ }^{1}$ Dosen Program Studi Farmasi, Fakultas Ilmu Kesehatan, Universitas \\ Muhammadiyah Palangkaraya, Jl. RTA. Milono Km. 1,5 Palangka Raya, \\ Kalimantan Tengah \\ e-mail : guntursatriopratomo@yahoo.com
}

\begin{abstract}
ABSTRAK
LATAR BELAKANG. Gerakan Keluarga Sadar Obat (GKSO) adalah program yang dicanangkan oleh Ikatan Apotoker Indonesia (IAI) yang merupakan upaya bersama untuk meningkatkan pemahaman masyarakat terhadap obat melalui sosialisasi DAGUSIBU (Dapatkan, Gunakan, Simpan, dan Buang) obat dengan benar.Berdasarkan observasi di lapangan, masyarakat di lokasi sasaran pengabdian masih banyak yang kurang sadar mengenai peran penting dan berbahanya obat serta jangka waktu terapi obat. Perilaku masyarakat yang sering terjadi adalah masih belum bias membedakan mana obat golongan bebas, bebas terbatas, obat keras, psikotropika dan narkotika sesuai dengan kegunaan serta kesesuaian dengan penyakitnya, masih menyimpan obat yang tidak digunakan, dan membuang secara sembarangan untuk obat yang sudah di pakai.memprakarasi pengobatan sendiri tanpa berkonsultasi dengan tenaga kesehatan, menggunakan obat atas dasar informasi dari keluarga dan tetangga dan belum sadar akan pengaruh makanan terhadap dosis tertentu.

METODE.Metode pelaksanaan kegiatan adalah dengan menggunakan metode penyuluhan.

HASIL.Kegiatan yang dilakukan adalah dengan memberikan penyuluhan kepada masyarakat desa Tabore. Materi yang disampaikan adalah mengenai Gerakan

Keluarga Sadar Obat dengan berfokus pada DAGUPIPISIBU (Dapatkan, Gunakan, Pilih-pilih, Simpan, dan Buang) obat dengan benar, meliputi: (1) Agar obat memberikan manfaat dan keamanan bagi anda ingatlah DAGUPIPISIBU; (2) Dapatkan obat dengan benar gunakan obat dengan benar buang obat dengan benar simpan obat dengan benar; (3) Dapatkan obat dengan benar tempat pelayanan obat resmi adalah Apotik; (4) Konsultasi dengan apoteker di Apotik untuk mendapatkan obat yang aman, bermanfaat dan berkualitas; (5) Konsultasi dengan Apoteker di Apotik agar dapat menggunakan obat dengan benar; (6) Konsultasi dengan Apoteker di Apotik karena setiap obat memerlukan kondisi penyimpanan yang berbeda dan (7) Konsultasi dengan Apoteker di Apotik agar dapat membuang obat dengan benar.

KESIMPULAN: Kegiatan ini merupakan salah satu upaya dalam meningkatkan ketepatan Swamedikasi masyarakat yang selama ini dilakukan tanpa pengawasan sebagai salah satu upaya untuk meningkatkan derajat kesehatan masyarakat Indonesia khususnya masyarakat yang berada di daerah terpencil.
\end{abstract}

Kata Kunci : Gerakan Keluarga Sadar Obat (GKSO), desa Tabore Kecamatan Mentangai Kabupaten Kapuas Kalimantan Tengah 


\section{PENDAHULUAN}

Berdasarkan Undang-

Undang Nomor 36 Tahun 2009, telah ditetapkan Upaya Kesehatan sebagai kegiatan yang bertujuan untuk meningkatkan derajat kesehatan yang setinggi-tingginya bagi masyarakat dan salah satu upaya kesehatan adalah pengamanan dan penggunaan sediaan farmasi. Harapan terhadap derajat kesehatan yang setinggitingginya seperti yang tertuang dalam Undang-Undang Kesehatan tersebut sampai saat ini masih belum tercapai.Terkait berbagai masalah kesehatan khususnya mengenai obat masih banyak ditemui di masyarakat.Mulai penyalahgunaan obat, terjadinya efek samping yang tidak diinginkan dan sebagainya.

Dalam pelayanan kesehatan, obat merupakan komponen yang penting karena diperlukan dalam sebagian besar upaya kesehatan baik untuk menghilangkan gejala suatu penyakit, mencegah penyakit dan juga dapat menyembuhkan penyakit. Hal tersebut dapat terpenuhi apabila cara mendapatkan, cara menggunakan, cara menyimpan dan cara membuang obat dilakukan dengan baik dan benar. Namun, dilain pihak obat dapat menimbulkan efek samping yang tidak diinginkan jika penggunaannya tidak tepat serta dapat berdampak pada pencemaran lingkungan jika penanggulangan limbah obat tidak dikelola dengan baik.

Salah satuupaya yang dapat dilakukan untuk meningkatkan kesadaran masyarakat terhadap obat adalah dengan melakukan penyuluhan Gerakan Keluarga Sadar Obat.Gerakan Keluarga Sadar Obat (GKSO) adalah program yang dicanangkan oleh Ikatan Apotoker Indonesia (IAI) yang merupakan upaya bersama untuk meningkatkan pemahaman masyarakat terhadap obat melalui sosialisasi DAGUSIBU (Dapatkan, Gunakan, Simpan, dan Buang) obat dengan benar.Diharapkan dengan adanya penyuluhan yang dilakukan, masyarakat menjadi lebih sadar terhadap penggunaan obat dengan bijak dan benar, sehingga masyarakat terhindar dari dampak buruk akibat penggunaan obat yang tidak tepat.

\section{Gerakan Keluarga Sadar} Obat (GKSO) merupakan upaya meningkatkan kesadaran masyarakat dan sekaligus 
mencerdaskan masyarakat dalam berperilaku sehat, khususnya terkait dengan obat.Secara nasional gerakan ini merupakan yang pertama kali dilakukan di Indonesia walaupun sebenarnya upaya meningkatkan kesadaran masyarakat tentang obat telah banyak dilakukan baik secara individu maupun secara kelompok bahkan secara resmi oleh institusi terkait.Dengan demikian gerakan ini merupakan akumulasi dinamika yang menyadari pentingnya melakukan gerakan secara nasional untuk mempercepat tercapainya kondisi masyarakat yang sadar dan selanjutnya menjadi cerdas serta mampu secara mandiri melakukan perilaku sehat dan bertanggungjawab, khususnya terkait dengan obat.Dalam pelaksanannya tentu kegiatan ini tidak lepas dari hal-hal yang bersifat hambatan baik internal (kelemahan) maupun eksternal (ancaman) serta hal-hal yang bersifat dukungan baik internal (kekuatan) maupun eksternal (peluang).Secara garis besar perkiraan keadaan tersebut dapat diuraikan sebagai berikut:

1. Kelemahan:

$$
\begin{array}{cr}
\text { - Kurangnya } & \text { kesadaran } \\
\text { apoteker untuk menjadi }
\end{array}
$$

tenaga profesi yang menjamin keamanan, kemanfaatan dan kualitas obat;

- Gerakan Keluarga Sadar Obat merupakan gerakan nasional baru yang melibatkan dan menuntut komitmen tinggi, sehingga memerlukan proses sosialisasi;

- Sedikitnya tenaga kesehatan yang berada di pelosok desa.

2. Ancaman:

- Kurangnya kesadaran masyarakat terhadap obat sebagai komoditi kesehatan yang juga dapat menentukan keberhasilan atau kegagalan pengobatan;

- Lemahnya dukungan infrastruktur kesehatan yang bertanggung jawab terhadap keamanan, kemanfaatan dan kualitas obat;

- Banyaknya informasi tentang obat yang hanya mengutamakan aspek bisnis sehingga meninggalkan fungsi edukasi bagi masyarakat;

- Krisis ekonomi, sosial, politik dan budaya di Indonesia memperburuk/memperlemah kondisi masyarakat sehingga 
mudah dipengaruhi oleh halhal yang tidak rasional.

3. Kekuatan:

- Pengabdian masyarakat sebagai salah satu program dalam Tri Darma Perguruan Tinggi dapat menjadi pendorong bagi tenaga pengajar khususnya di bidang kesehatan untuk secara aktifterlibat dalam Gerakan Keluarga Sadar Obat.

4. Peluang:

- Sistem Jaminan Kesehatan Nasional yang berasaskan pada upaya prefentif serta promotif berhubungan secara bermakna dan sejalan dengan Gerakan Keluarga Sadar Obat.

Sasaran dari pelaksanaan Pengabdian Masyarakat yang berjudul "Sosialisasi perilaku hidup bersih dan sehat pada anak-anak tingkat SD (sekolah dasar) di Desa Tabore Kecamatan Mentangai Kalimantan Tengah adalah anakanak usia sekolah dasar yang ada di Desa Tabore Kecamatan Mentangai Kalimantan Tengah. Desa Tabore merupakan salah satu desa yang terletak di Kecamatan Mentangai Kalimantan Tengah, bila dibandingkan dengan desa lain yang ada di Kalimantan Tengah Desa Tabore merupakan salah satu desa tertinggal.

Masyarakat di lokasi sasaran pengabdian masih banyak yang kurang sadar mengenai peran penting dan berbahanya obat serta jangka waktu terapi obat. Perilaku masyarakat yang sering terjadi adalah masih belum bias membedakan mana obat golongan bebas, bebas terbatas, obat keras, psikotropika dan narkotika sesuai dengan kegunaan serta kesesuaian dengan penyakitnya, masih menyimpan obat yang tidak digunakan, dan membuang secara sembarangan untuk obat yang sudah di pakai. memprakarasi pengobatan sendiri tanpa berkonsultasi dengan tenaga kesehatan, menggunakan obat atas dasar informasi dari keluarga dan tetangga dan belum sadar akan pengaruh makanan terhadap dosis tertentu.

Sesuai dengan konsep Sistem Kesehatan Nasional, Kesehatan menjadi tanggung jawab seluruh bangsa, tidak terbatas hanya pada tenaga kesehatan saja.Oleh karena itu, untuk mewujdkan derajat kesehatan yang setinggi-tingginya bagi masyarakat diselenggarakan 
upaya kesehatan yang terpadu dan menyeluruh dalam bentuk upaya kesehatan perseorangan dan upaya kesehatan masyarakat.Upaya kesehatan dilakukan dalam bentuk kegiatan dengan pendekatan promotif, preventif, kuratif dan rehabilitatif secara terpadu, menyeluruh dan berkesinambungan.

Solusi yang ditawarkan adalah dilakukannya penyuluhan Gerakan Keluarga Sadar Obat (GKSO) yang bertujuan untuk memberikan pengetahuan terhadap masyarakat, khususnya masyarakat di Desa Tabore tentang cara memperlakukan obat dan melakukan pengobatan secara mandiri dengan tepat dan optimal.Diharapkan dengan adanya penyuluhan ini menjadi sumbangan pengetahuan kepada masyarakat dalam penggunaan obat yang baik dan benar dan diharapkan dapat membantu program pemerintah dalam meningkatkan derajat kesehatan masyarakat. Kegiatan yang dilakukan adalah:

1. Penyuluhan mengenai DAGUPIPISIBU (Dapatkan, Gunakan, Pilih-pilih, Simpan, dan Buang) obat dengan benar.

2. Memantau perkembangan dan mencatat semua hasil penyuluhan terhadap hasil kegiatan yang dilakukan oleh masyarakat desa Tabore setelah diadakan penyuluhan.

\section{METODE PELAKSANAAN}

Metode pelaksanaan kegiatan menggunakan metode penyuluhan.Kegiatan dilaksanakan pada hari Minggu tanggal 20Desember 2015.Kegiatan ini dimulai dari pukul 10.00-13.00 WIB.Kegiatan dilakukan di salah satu rumah warga yang diikuti oleh warga masyarakat Desa Tabore. Kegiatan dimulai dengan adanya pembukaan dari Kepala desa Tabore yang kemudian dilanjutkan dengan perkenalan dan penyampaian materi oleh tim pelaksana. Dalam kegiatan dilakukan penyampaianmateri dengan menggunakan powerpoint, penayangan video tentang program DAGUPIPISIBU. Selain itu dibuka sesi tanya jawab untuk menilai sejauh mana tingkat pemahaman warga terhadap materi yang disampaikan sekaligus pembagian hadiah bagi warga yang dinilai aktif selama kegiatan berlangsung.

\section{HASIL DAN PEMBAHASAN}

Kegiatan pengabdian yang dilakukan merupakan salah satu peran dari institusi pendidikan untuk 
membantu program pemerintah dalam meningkatkan derajat kesehatan masyarakat.Kegiatan yang dilakukan adalah dengan memberikan penyuluhan kepada masyarakat desa Tabore. Materi yang disampaikan adalah mengenai Gerakan Keluarga Sadar Obat dengan berfokus pada

DAGUPIPISIBU (Dapatkan,

Gunakan, Pilih-pilih, Simpan, dan

Buang) obat dengan benar, meliputi:

1. Agar obat memberikan manfaat dan keamanan bagi anda ingatlah DAGUPIPISIBU

2. Dapatkan obat dengan benar gunakan obat dengan benar buang obat dengan benar simpan obat dengan benar

3. Dapatkan obat dengan benar tempat pelayanan obat resmi adalah Apotik.

4. Konsultasi dengan apoteker di Apotik untuk mendapatkan obat yang aman, bermanfaat dan berkualitas.

5. Konsultasi dengan Apoteker di Apotik agar dapat menggunakan obat dengan benar.

6. Konsultasi dengan Apoteker di Apotik karena setiap obat memerlukan kondisi penyimpanan yang berbeda.
7. Konsultasi dengan Apoteker di Apotik agar dapat membuang obat dengan benar.

Potret permasalahan yang terjadi di lapangan adalah tidak adanya fasilitas kesehatan yang memadai.Sehingga untuk memperoleh jasa pelayanan kesehatan mereka harus menempuh perjalanan yang jauh dengan akses yang sulit untuk ditempuh. Kedatangan tim pengabdian masyarakat Universitas Muhammadiyah Palangkaraya ke desa Tabore mendapatkan respons yang sangat baik serta antusiasme yang tinggi dari warga setempat. Masyarakat desa Taboresangat antusias ketika diberikan penyuluhan mengenai penggolongan obat yang harus diperhatikan.Masyarakat dikenalkan dengan logo dan tanda yang tertera pada obat keras, obat berbatas, dan obat bebas.

\section{KESIMPULAN}

Kegiatan ini merupakan salah satu upaya dalam meningkatkan ketepatan Swamedikasi masyarakat yang selama ini dilakukan tanpa pengawasan.Dengan tumbuhnya kesadaran untuk menggunakan obat dengan benar masyarakat diharapkan mampu menerapkan Swamedikasi sehingga terhindar dari 
masalah kesehatan. Sehingga dapat disimpulkan bahwa kegiatan ini merupakan langkah awal dalam meningkatkan derajat kesehatan masyarakat Indonesia khususnya masyarakat yang berada di daerah terpencil.

\section{DAFTAR PUSTAKA}

Pengurus Pusat Ikatan Apoteker

Indonesia, 2014. Pedoman

Pelaksanaan Gerakan Keluarga

Sadar Obat GKSO) : Jakarta. 